\title{
MEDICINE IN ART
}

\author{
Terence Cawthorne, F.R.C.S. \\ President of the Harveian Society of London, 1960
}

THIs evening I would like to discuss with you some of the paintings and sculpture which I have enjoyed looking at and which have also aroused my interest as a doctor.

Most of what I am going to show you was created before the 18 th century, for it was from the Renaissance to the end of the 18 th century that painting and sculpture was made possible through the patronage, first of the Church and later the aristocracy, both of whom were more likely to encourage artists to depict persons and historical events rather than the impersonal landscapes so popular in recent times.

And so, if I do not show you many I 9 th or 20 th century paintings, it is not because I do not like them, but because they do not fit in with my theme which might well be entitled 'A Doctor looks at Art'. We must remember that many of the great artists were compelled to respect the wishes and views of their patrons and in order to do this, but at the same time infuse life into their pictures, they had to make their medical suggestions somewhat indirectly.

In some of the instances which I shall give, you may well think that the medical interest in the picture is purely in the eye of the beholder, and in that you may well be right, which is why I call this talk 'A Doctor looks at Art'.

But before we do this, why not let us see two examples of the artist looking at the doctor?

\section{Agostino and Niccola della Torre (1515), by Lorenzo Lotto (National Gallery) (Fig. I)}

This picture of two brothers was painted in Venice in 1515. The foremost figure is clearly that of a physician. In his left hand he holds a book of 'Galenicals', while in his right he holds a towel on which is a fly, attracted possibly by the medical uses to which the towel has been put. At his neck is a cord rather like a bootlace which might well have been used as a tourniquet in blood-letting. On the desk there is the usual litter of books, pamphlets, prescriptions and even

\footnotetext{
Presidential Address to the Harveian Society of London, Fanuary 18, 1961 .
}

instruments that to this day can be seen covering the busy doctor's desk; though important looking books took the place of the unopened medical journals now seen.

The second example is the painting of Dr. Gachet by Van Gogh. Dr. Gachet ran a private sanatorium for psychiatric patients at Auvers-surSeine, some 30 miles from Paris. He was intensely interested in art and in artists, many of whom were his friends and a few, including Van Gogh, his patients. When Van Gogh decided to leave Arles in the south and return to near Paris in 1890 , it was suggested that he should go to Dr. Gachet's sanatorium. This he did for his behaviour had been getting more and more eccentric and his painting, though often grand, was very erratic.

During the 79 days that he was with Dr Gachet he painted 80 pictures, including the one you see now, and then one hot, sunny day in a field he shot himself and died two days later.

In a letter to Gaugin he writes of the picture: 'I have now done a portrait of Dr. Gachet wearing a distressed expression typical of our times'.

Van Gogh's way of indicating the doctor's profession is to show him holding a leaf of the digitalis plant.

Now the first introduction to medicine for most of us was the dissecting room. In 'The Justice of Cambyses', by Gerard David (Bruges), which was commissioned about I49I by the Aldermen of Bruges, we see how King Cambyses dealt with one of his corrupt judges by having him flayed to death, a story told by Herodotus. It might well be that the City Fathers of Bruges were beset by corruption and that they hoped such a picture would be a gentle reminder of the fate that might befall those who enriched themselves at the city's expense.

When we have finished our pre-clinical studies and pass on to hospital, our earliest contact with the living patient is in the casualty department, where there is plenty of opportunity to study the surgery of trauma. This is a constantly recurring theme in the earlier painters of the Renaissance, most of whose subjects had to be religious and so often portrayed the martyrdom of saints. 


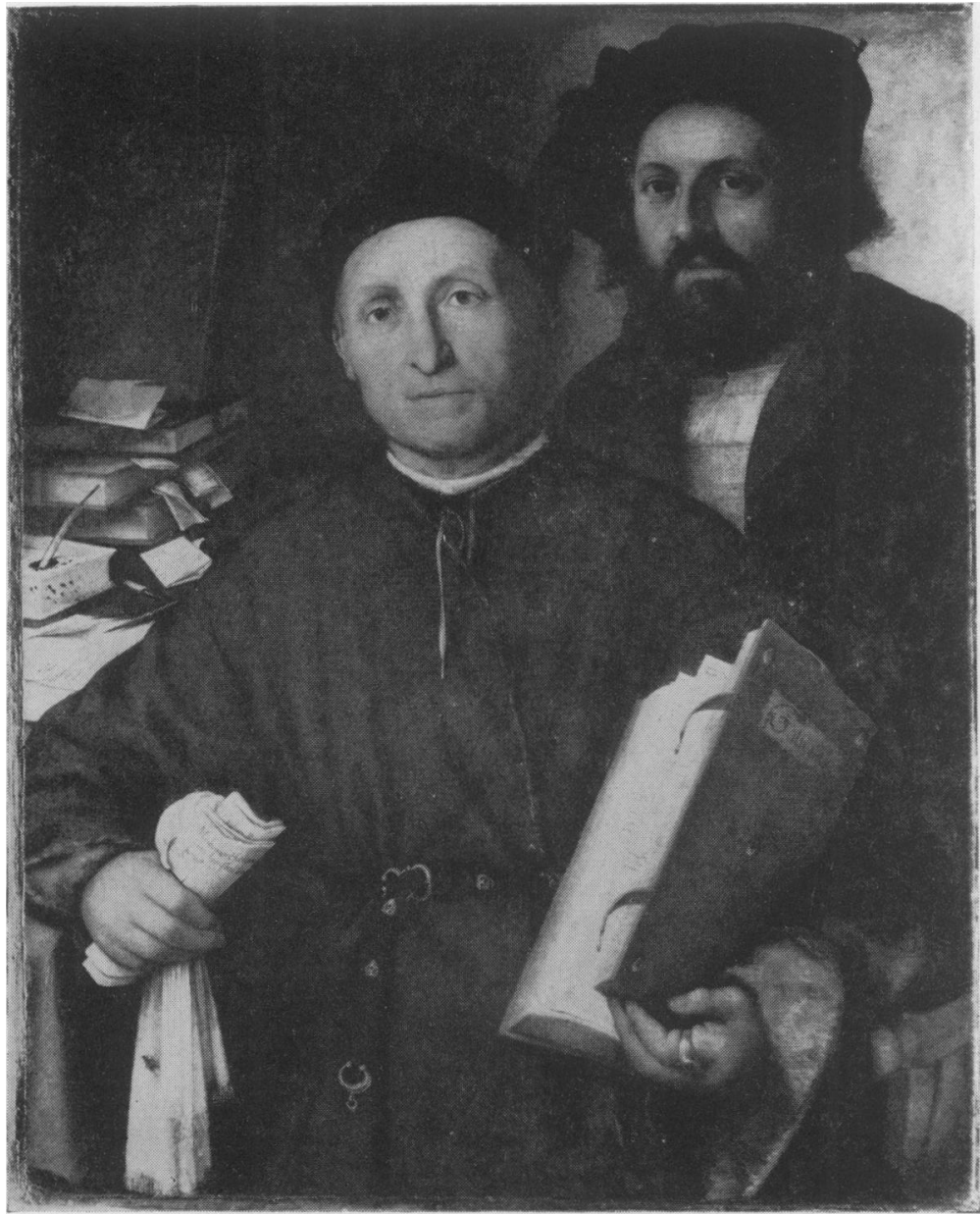

Fig. I.-'Agostino and Niccola de'la Torre '-Lorenzo Lotto.

Reproduced by courtesy of the Trustees, The National Gallery, London.

A great favourite in those days was St. Sebastian, and I have never been in a gallery of any size where there were not several St. Sebastians. The National Gallery has four and the greatest both in size and in conception is without doubt that by the brothers Pollaiuolo.

\section{St. Sebastian, by Antonio and Piero Pollaiuolo (National Gallery) (Fig. 2)}

St. Sebastian was a captain of the Prætorian Guard in the time of the Emperor Diocletian. When the Emperor found that Sebastian had turned Christian he ordered that Sebastian be bound to a tree and shot to death with arrows. This took place near the Catacombs, a short distance outside the gates of Rome on the Appian Way. In this large picture which hangs in the National Gallery, London, the soldiers are seen busy at their task while in the background can be seen part of Rome with a Roman triumphal arch and the River Tiber. Despite the short range and numerous arrow wounds, Sebastian survived and was cared for by a Christian lady, only to be arrested again and stoned to death. At the scene of the martyrdom by the Catacombs of St. Sebastian stands the Basilica of St. Sebastian whose greatest treasure is one of the arrows which is said to have been used against the saint. The Pollaiuolos were metal workers and sculptors before taking to painting, and this is, perhaps, their most famous picture.

It has been suggested that the reason for the popularity of the Martyrdom of St. Sebastian was the opportunity it afforded artists of portraying the male nude! This is more obvious in the 'Sebastian' by Reni (Borghese Gallery, Rome), which shows a very glamorous saint quite unconcerned by his wounds.

Still on the subject of trauma, let us now consider the Florentine painter Piero di Cosimo. 


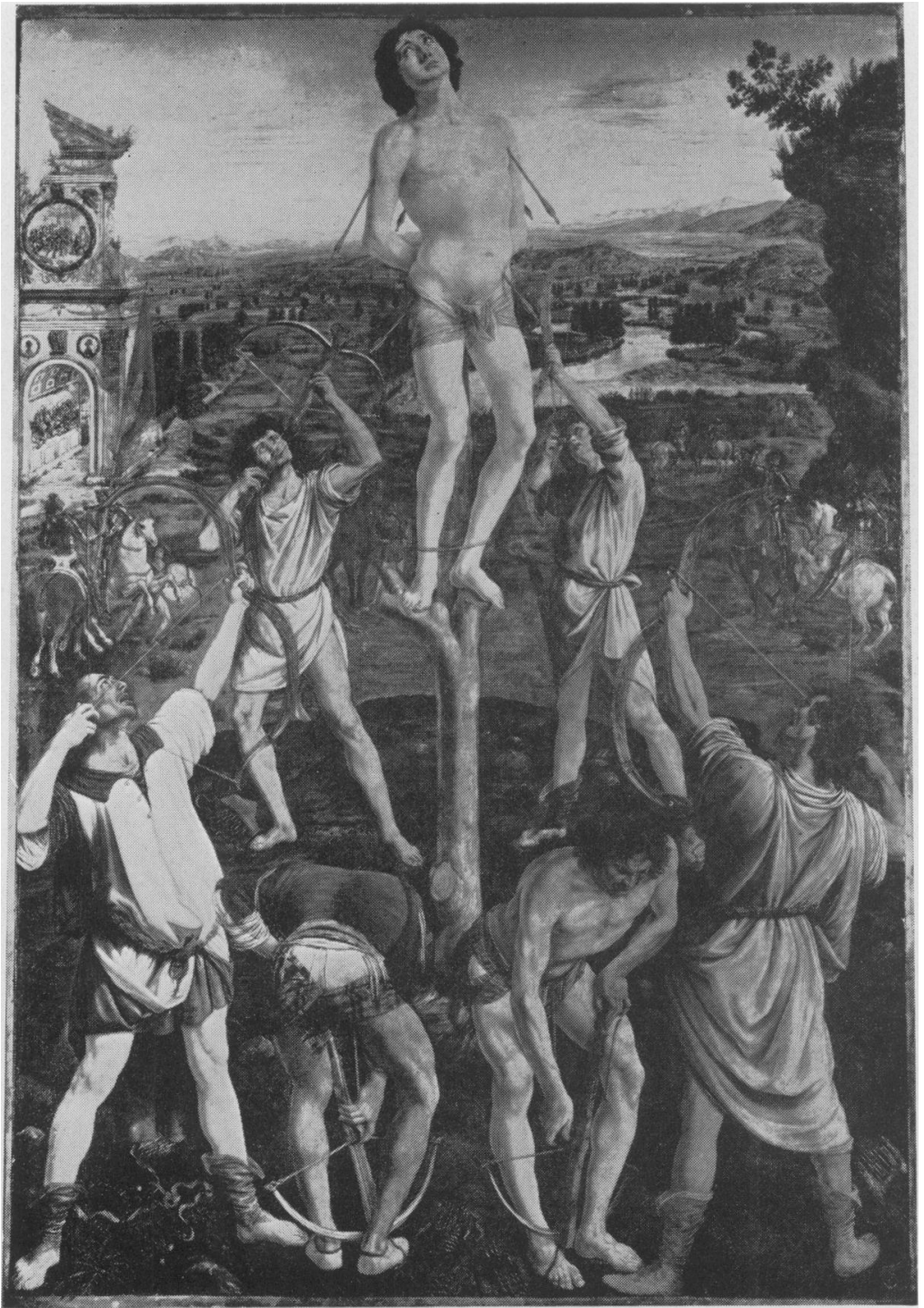

FIG. 2.- 'St. Sebastian'-Antonio $\frac{\partial}{\partial}$

and Piero Pollaiuolo. National Gallery, London.

Taking the name Cosimo from his teacher, Cosimo Rosselli, whom he accompanied to Rome to work on the frescoes in the Sistine Chapel, his real interest was in mythological subjects in which he was encouraged by his patron, Lorenzo di Medici.

His painting, The Death of Procris, hangs in the National Gallery, London, and shows the unfortunate Procris fatally wounded by a magic arrow from the bow of Cephalus. Magic because these arrows always found their mark, this time a nasty wound in the upper part of the trachea. She is mourned by a gentle faun. The large hound in the foreground and the curious and probably extinct animals on the foreshore serve to accentuate the mythological character of the $\frac{D}{2}$ subject. There is another very striking, vivid picture, full of trauma, by $\mathrm{Di}$ Cosimo in the $\sigma$ National Gallery in which the Centaurs are N engaged in a life and death struggle with the N Lapithæ. Apart from the battle the luminous 0 treatment of the background sky reminds one somewhat of our present-day Algernon Newton.

An interesting neuro-surgical procedure is $\stackrel{\oplus}{\oplus}$ seen in a picture by Heironymous Bosch, the $15^{\text {th }} 7$ century Flemish painter, which hangs in the $\overrightarrow{0}^{\circ}$ Prado Museum in Madrid, called 'The Cure of $\overrightarrow{\mathbb{D}}$ Folly'. It shows a lunatic submitting to being $\underset{\mathbb{D}}{\mathbb{Q}}$ 


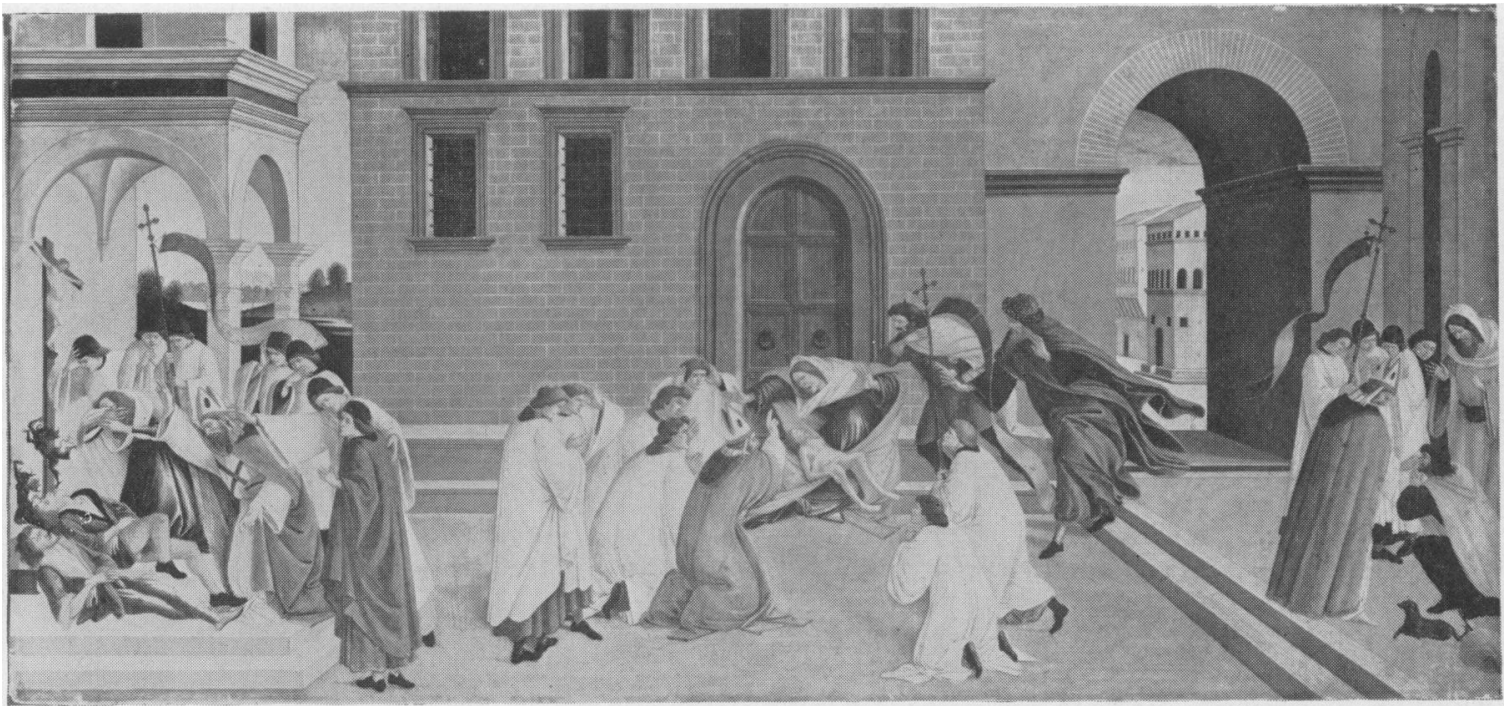

Reproduced by courtesy of the Trustees, The National Gallery, London.

FIG. 3.- 'The Miracles of St. Zenobius '-Sandro Botticelli.

trephined. The surgeon wears a funnel which is said to denote foolish eagerness, while the lady, who might well be the theatre sister, has a book on her head to indicate idle pomposity. The gentleman with a jug was obviously meant to be the anæsthetist. This forms part of a series illustrating the seven deadly sins, which was among Bosch's earliest work. A curious painter, thought by some to be schizophrenic, he was not to everyone's taste, but his work was much sought after by Philip II of Spain, himself a curiously withdrawn man whose great empire at that time included the Low Country. This is why the Prado is so rich in the pictures of this curious artist.

Let us now leave the rather crude and sordid subject of surgery, and turn to healing, and healing by miracle was a favourite theme for the Renaissance painters. A particularly interesting example is The Miracles of St. Zenobius, by Sandro Botticelli, the $15^{\text {th }}$ century Florentine painter. One panel which is now shown (Fig. 3) hangs in the National Gallery, London, and is of particular interest because it is painted in Botticelli's later years after he had been influenced by the martyrdom of the monk Savonarola, who preached against the wickedness of the times and was eventually burned at the stake in the Piazza della Signoria, Florence.

Turning away from the mythological subjects which made him so famous, Botticelli adopted an entirely different style, a style which has since been copied by many modern artists, notably Chirico. The subject of this picture was St. Zenobius, patron and first Bishop of Florence. He is credited with many miraculous cures, some of which are shown here.

By contrast let us now look at one of Botticelli's earlier and possibly his most famous picture, 'The Birth of Venus'. It hangs in the famous Uffizi Gallery in Florence. There is little to remind one of medicine here except perhaps the cyanotic appearance of the cherub who is blowing himself blue to provide a zephyr for the occasion. This blue-faced boy is more obvious in the actual picture than in reproduction.

Psychological medicine is recalled in many works of art, but in none more strikingly than the head by the I $7^{\text {th }}$ century Roman sculptor, Bernini, whose 'Anima Damnata' in the Palazzo di Spagna, Rome, is the very essence of a tortured and damned soul. Bernini was the son of an indifferent sculptor, and in early youth was attached to the household of the powerful Cardinal Borghese. Among his tasks was that of laying the table, and he exercised his budding talent in sculpturing the rolls of butter into various designs and shapes. The cardinal, intrigued by this, asked his majordomo who was responsible for shaping the butter into these designs. The major-domo, fearing that the lad would be punished, excused his conduct, but the Cardinal encouraged the boy and had him taught so that in the end he became one 
of Rome's greatest sculptors, second possibly only to Michaelangelo.

While we are still on the subject of psychological medicine let us turn again to that tortured but talented soul, Van Gogh.

Acclaimed as a genius today, he sold but one picture in his lifetime, and that went for but a few francs to his brother, Theo, who, though he believed in Vincent's great talent, probably only bought the picture to encourage his despairing brother. Poor Theo died soon after Vincent shot himself, and they lie buried together in the churchyard at Auvers.

One of Van Gogh's many self-portraits hangs in the Courtauld Institute of Art in Woburn Square, London. It was painted in the south of France while he was still suffering from the selfinflicted wound when he cut off a portion of his ear and sent it to a barmaid (or was it a prostitute)?

Another picture by Van Gogh hangs in the Museum of Modern Art in New York and is a little gem of perspective. It shows one of the corridors in the asylum at St. Remy where he was confined during a maniacal bout in 1889 .

Having during the war seen quite a lot of the inside of mental hospitals, there is no mistaking the long corridors faced with glazed tiles.

The final picture under this heading is to be found in the National Gallery, London, and it is by the 16th century Spanish painter, El Greco, the subject being ' Christ Driving the Traders out of the Temple'. This vivid picture of Our Lord in His righteous wrath, hitting out right and left at the evil-doers, always makes me feel that a copy should hang in every juvenile court, though psychologically speaking it may be quite wrong for me to think along these lines. This is the third and last version of the subject and was painted in 1604 when he had been living in Toledo for some years. It differs considerably from the earliest painted in 1572 when he was still living in Italy and very much under the influence of his teachers, Titian and Tintoretto. In the later picture, however, he has retained a little bit of Venice for a glimpse of the Grand Canal can be caught through the arch of the Temple.

All the great masters were very much at the beck and call of their patrons and they had to make the most of the human material available to them, and in the case of portraits the material was often not very interesting artistically.

Consequently, when left to their own devices, these artists chose faces and figures of character and of interest from the artistic point of view. This often meant old and indigent subjects and so we turn to Geriatrics for some of our greatest artistic treasures.

Rembrandt was the outstanding painter of old men and I think that the picture of an old man, which hangs in the Hermitage Collection in Leningrad, is the outstanding picture of old age which I have seen.

Another striking example, this time of an old peasant woman, is in the Accademia in Venice andoㅎ? is by Giorgione, the Venetian painter of the 15 tho century who was a contemporary of Titian.을 Unfortunately he died of plague at the early age of 34 , which he caught by visiting the sick-bed of his betrothed, who was dying of the disease.

We reach the borderland of geriatrics and ${ }^{\infty}$ dermatology in the intimate portrait by Ghirlandajo of 'An Old Man and His Grandson', $\vec{\omega}$ which hangs in the Louvre in Paris. This is a. touching picture of an old man made ugly ando ridiculous by rhinophyma and his little grandson 3 . who sees no ugliness and nothing to laugh at. Thew kindness and gentleness underneath that hideous mask shines through to wipe out the deformity. N

Now let us turn to orthopædics, which offers $\vec{\infty}$ many interesting subjects in art.

Portrait of a Nobleman, by Giovanni Moroni음 (National Gallery) (Fig. 4), shows a youngish man,elegantly dressed; you will notice that from the toes of one foot a cord passes to the knee and this was clearly for the purpose of correcting a foot $-\overrightarrow{0}$ drop which was presumably the sequel of infante? paralysis.

The Spanish school of painters often chosed dwarfs and other deformed persons as subjects for painting, possibly because they were to be found ao lot in Court circles where they were treated as a kind of lap-dog-cum-servant.

Diego Velasquez, the Court painter of Philip I V흑 in the $17^{\text {th }}$ century, has left behind a remarkable collection of such paintings. Perhaps his greatest and certainly his biggest is 'Las Meninas' which shows the Royal children playing with an $\frac{0}{3}$ achondroplastic dwarf, who steals the picture. Also in the Prado Museum is a portrait of a dwarf 3 . clearly quite compos mentis and normal except foro his size, who gazes at you with all the sadness in the world in his eyes that he cannot be as othero men. There are four of these pictures in the Velasquez room in the Prado, and one can onlyo marvel at the genius of Velasquez who had the power to put all this in a picture so vividly as too evoke the thoughts that I have just mentioned to you.

For an example of ophthalmology, I am going ${ }_{\sigma}^{\omega}$ to ask you to come with me to Bruges, to the Communal Museum, to see a fine example of Jan van Eyck. This is called 'The Virgin and? Canon van der Peale', and is an interesting and very beautiful example of the way in which theo

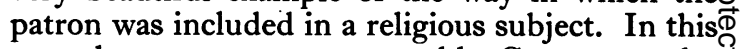
case the patron was presumably Canon van der市 


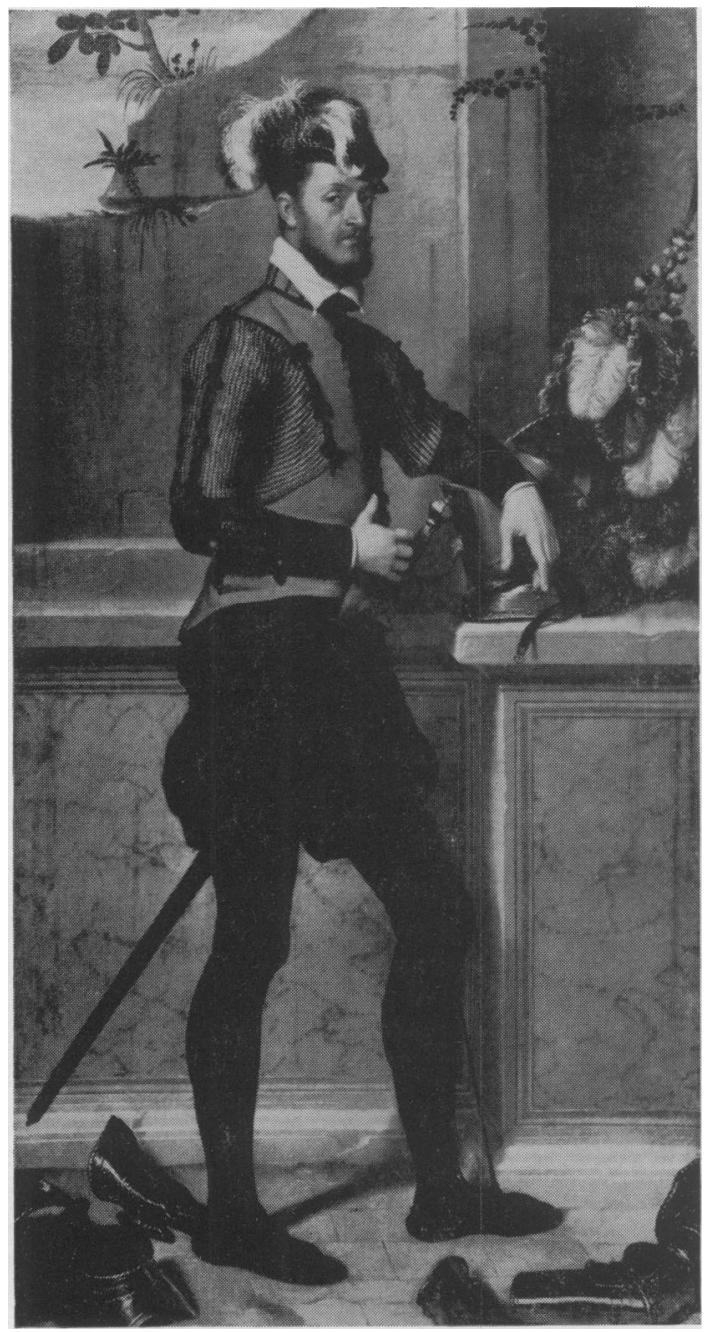

Reproduced by courtesy of the Trustees, The National Gallery, London.

FIG. 4.-' Portrait of A Nobleman '-Giovanni Moroni.

Peale and just to show how up-to-date he was, he insisted on being painted holding a pair of pincenez spectacles! This is, I think, the first time that spectacles had been seen in a picture, and it was in the 14th century that spectacles came into use.

Now let us look at some later pictures by Goya, Court painter to Charles II of Spain. He was famed for and made his fortune from portrait painting. His portrait of Dr. Seral, a Spanish financier, shows that this man had suffered from a stroke which had affected his right arm and also the right side of his face which is drawn up in contracture as is often seen after imperfect recovery from facial palsy. Another, and to me particularly interesting, aspect of Goya is the effect that his total deafness (which suddenly came upon him in the middle 40's) had upon his imaginative painting. Whereas before his deafness he chose cheerful, bucolic subjects with delicate colours, his deafness changed his style entirely so that he chose to depict morbid and sordid subjects often in the most sombre of colours. I should add that his illness did not in any way interfere with his portrait painting.

One of his pictures before his deafness shows a gay picnic scene, and another the Spanish version of the well-known game of blindman's buff. Then after his deafness, his choice of subjects changed to the sombre, the macabre, the weird and at times the disgusting. One shows two old men eating porridge and the black and sombre colours reflect his mood which, I believe, was the result of his deafness. Another one is of the giant, Saturn, devouring one of his young. All these four pictures are in the Prado Museum in Madrid, which houses a remarkable and extensive collection of Goya pictures, tapestries and drawings.

The effect of sudden and total deafness upon Goya's artistic output has its parallel in the output of another creative artist in a different form, one century earlier. I refer to Dean Swift who was tortured with deafness and giddiness as the result of bilateral Ménière's disease, and as he became more deaf so was this reflected in the character of his writings.

Now I would like to show you two great pictures, each of which has, I think you will agree, an obstetric motif.

The first is by Van Eyck and it hangs in the National Gallery, London, and is one of his bestknown pictures. The Arnolfini's were merchants of Italian origin and in the picture we are witnessing (according to some accounts) the wedding (and to other accounts) the betrothal of Arnolfini. Whether it be wedding or betrothal, even to my inexpert glances there is not a moment to lose for sweet though she looks, the young lady is clearly in the last few weeks, if not days, of pregnancy.

For my last picture I have chosen my favourite 'The Burial of Count Orgaz' by El Greco. It graces the Church of St. Thome in Toledo, Spain, where it forms the altarpiece of the side chapel. Perhaps its greatest interest is that in it are combined El Greco's two styles-the spiritual, in which the figures are often so indistinct and elongated to have given rise to the theory that the artist suffered from a visual disturbance, and the temporal which is seen in the lower half of this picture. There you will see that the details of the clothing, the faces and the surroundings are almost photographic in the faithfulness of their reproduction. Many faces, well-known at the 
time, were included in the lower and temporal part of the picture, including El Greco himself and his son, Jose. What adds to my interest in this picture is that when I stayed in Toledo one of the waiters in the hotel might have been a model for one of the figures. No doubt it was one of his ancestors some 300 years before. The picture was commissioned by the Church Fathers of San Thome to commemorate their benefactor, Count Orgaz.

It is sad to have to relate that El Greco had great difficulty in getting what he thought was a proper price for the picture. Eventually, after much wrangling, he received what would now amount to some $£ 300$ (a very large sum for those days) and it has been said that the owners have refused in recent times a thousand times that sum.

The picture shows the dead Count being lowered into his grave by the Bishop of Toledo, aided by the clergy, and witnessed by the leading citizens. At the same time up above, his sout wrapped in a caul, is being delivered through rift in the clouds back into the Kingdom of Heaven.

Now it was on my second of many visits to loak at this picture that I imagined that this rift in the clouds through which the angel midwife was delivering his soul, was in the form of the huma birth canal or vagina, and, indeed, how vefig appropriate for it to be so shaped. I feel quite sure that this is what $\mathrm{El} \mathrm{Greco}$ intended when he painted this remarkable picture.

And so you see how artists throughout the ages have been able to capture the interest of theow patrons and followers and have been able to evorese interest and emotions, sometimes unconsciousl but usually deliberately, though sometimeg imperceptibly. 